\title{
A co-inoculation technique to rapidly screen citrus hybrids for resistance to both Alternaria Brown Spot caused by Alternaria alternata and Citrus Scab caused by Elsinoë fawcettii
}

\author{
Malcolm Wesley Smith ${ }^{1}$, Debra Lorraine Gultzow ${ }^{1}$, Toni Karen Newman ${ }^{1}$, \\ Sigrid Carola Parfitt ${ }^{1} \&$ Andrew Keith Miles ${ }^{2}$
}

\begin{abstract}
SUMMARY
A simple and inexpensive technique has been developed to allow the simultaneous screening of young hybrid seedlings for susceptibility to Alternaria Brown Spot (ABS) caused by Alternaria alternata and Citrus Scab (CS) caused by Elsinoë fawcettii. It is employed within six months of seed sowing, prior to hybrids being field planted, and has significantly improved breeding efficiency. By using the same culture techniques to multiply each pathogen, greater flexibility and ease of inoculation has been achieved. Plates of each pathogen are scraped/macerated to remove spores and other colony-forming units, strained through a coarse filter, combined and immediately sprayed onto vigorously growing seedlings. These seedlings are then incubated at $\sim 25^{\circ} \mathrm{C}$ and high humidity for 4-7 days before being returned to the greenhouse. Hybrids susceptible to ABS develop symptoms within two weeks and are immediately discarded. A second round of culling is performed after four weeks when CS symptoms have expressed. The process is repeated three times to minimise 'disease escapes' and has virtually eliminated these diseases from our field plantings of new hybrids. Nucellar seedlings of genotypes known to be resistant and/or susceptible to each pathogen were used to confirm that mixing the two pathogens did not cause a change in symptom development for either disease.
\end{abstract}

Index terms: breeding, genetic resistance, pathogen, fungal diseases.

\section{Técnica de co-inoculação para rastrear rapidamente híbridos de citros para resistência a mancha marrom alternária e verrugose dos citros}

\section{RESUMO}

Uma técnica simples e barata foi desenvolvida para permitir a rastreabilidade simultânea de mudas híbridas jovens de citros quanto à suscetibilidade a mancha marrom de alternária (MMA) causada por Alternaria alternata e verrugose dos citros causada por Elsinoë fawcettii. O teste foi realizado seis meses após a semeadura de sementes, antes dos híbridos serem plantados no campo e melhoraram significativamente a eficiência de reprodução. Ao utilizar as mesmas técnicas de cultura para multiplicar cada patógeno, conseguiu-se maior flexibilidade e facilidade de inoculação. As placas de cada patógeno são raspadas e maceradas para remover esporos e outras unidades formadoras de

\footnotetext{
${ }^{1}$ Bundaberg Research Station, Department of Agriculture \& Fisheries, Queensland, Australia

${ }^{2}$ Research \& Development for Primary Industries Pty Ltd, Queensland, Australia

Corresponding author: Malcolm Wesley Smith, Bundaberg Research Station, Department of Agriculture \& Fisheries, 49 Ashfield Road, Queensland 4670, Australia. E-mail: malcolm.smith@daf.qld.gov.au
} 
colônias, filtradas com um filtro, misturadas e imediatamente pulverizadas em mudas com crescimento vigoroso. Estas mudas são então incubadas a $\sim 25^{\circ} \mathrm{C}$ e alta umidade durante 4-7 dias antes de serem devolvidas à estufa. Os híbridos suscetíveis a MMA desenvolvem sintomas dentro de duas semanas e são imediatamente descartados. Uma segunda rodada de descarte é realizada após quatro semanas, quando os sintomas da verrugose se manifestam. O processo é repetido três vezes para minimizar "escapes das doenças" e praticamente eliminou essas doenças das coleções de campo de novos híbridos. As mudas nucelares de genótipos conhecidos como resistentes e/ou suscetíveis, a cada patógeno, foram utilizadas para confirmar que a mistura dos dois agentes patogênicos não causou alteração no desenvolvimento de sintomas das doenças testadas.

Termos de indexação: melhoramento, resistência genética, patógeno, doenças fúngicas.

\section{INTRODUCTION}

Alternaria Brown Spot (ABS) (caused by a pathotype of Alternaria alternata) and Citrus Scab (CS) (caused by pathotypes of Elsinoë fawcettii) are long-standing disease problems in many citrus producing countries and yet solutions via genetic resistance have been poorly explored. ABS was first described in 1903 from Australia (Cobb, 1903) and has since become established in many climatically suitable regions around the world, particularly in recent decades. Researchers have long recognised the simple pattern of segregation for susceptibility (Hutton \& Mayers, 1988) and the ease with which germplasm can be tested for disease reaction (Pegg, 1966), and as a result many international breeding programs now screen material prior to commercial release. In the Australian breeding program, all hybrids are screened during the nursery phase and only genetically resistant seedlings are field-planted (Miles et al., 2015a).

The nature of Elsinoë spp. associations with Citrus spp. is diverse and confusing (Miles et al., 2015b) although it is generally accepted that two species (E. fawcettii and E. australis) are responsible for commercially important disease impacts (Timmer, 2000). Each of these species has several pathotypes which can be distinguished on the basis of their host range, and they have variable geographical distribution. E. fawcettii pathotypes are the most widely distributed and have a long history of causing CS disease in many parts of the world where temperatures and humidity permit (Fawcett, 1936). By contrast, E. australis pathotypes, such as those causing Sweet Orange Scab, although long established in South America (Bitancourt \& Jenkins, 1937) have still to become established in many other citrus producing countries, including Australia. Other pathotypes of E. australis are present in Australia but have been shown to be non-pathogenic to cultivated Citrus spp, (Miles et al., 2015b). Consequently our resistance breeding work, and the inoculation technique described below, are concerned with the E. fawcettii pathotype which commonly infects lemons and mandarins but not oranges. It should not be implied that this technique would work for pathotypes of E. australis, such as those causing Sweet Orange Scab.

Given its long history of commercial damage, striking visual symptoms, and wide geographical distribution, it is perhaps not surprising that CS was the first fungal disease for which clear genetic differences in susceptibility were demonstrated (Winston, 1923; Winston et al., 1925; Traub \& Robinson, 1937). Hybrids produced in 1909 further demonstrated that certain parents could transmit CS resistance to their off-spring (Swingle et al., 1931). Notwithstanding these genetic opportunities, the widespread application of fungicides to control other diseases, combined with the serendipitous choice of genetically resistant commercial varieties have seen the importance of CS generally decline over the last half century, in most citrus types other than lemons.

However, this situation is changing as chemical registration, residue and trade restrictions force a rethink of current orchard management practices. A reduced need for fungicide applications, made possible by the development of new varieties resistant to ABS, could also see the emergence of diseases like CS that are currently supressed by non-target sprays. Changing from old varieties like 'Imperial' mandarin, which is genetically resistant to $\mathrm{CS}$, to newer commercial varieties like Afourer mandarin, which is highly susceptible to CS, could further alter disease dynamics. Such a scenario has already played-out in our breeding program where field progeny blocks of ABS-resistant hybrids have removed the need for fungicide applications, which has resulted in an increased incidence and severity of CS. If citrus growers are to gain the full benefit of ABS resistance and the resulting reduced fungicide applications, then it is important that the breeding program also address opportunities to incorporate genetic resistance to CS. 


\section{MATERIALS AND METHODS}

Field survey: Field progeny blocks at Bundaberg Research Station were assessed for the presence of ABS and CS after more than five years without fungicide application. Data were recorded on disease incidence and severity for families containing at least 20 hybrids. There were 209 such families, produced from 95 different parents, totalling 19,659 individual hybrids. This data was analysed to determine the genetic control of disease resistance/susceptibility.

Pathogen preparation and application: Virulent isolates of both $A$. alternata and $E$. fawcettii were developed from symptomatic mandarin leaves collected at Bundaberg Research Station. After pathogenicity testing, the most virulent isolates were stored at $\sim 6^{\circ} \mathrm{C}$ on half-strength potato dextrose agar $(1 / 2 \mathrm{PDA})$ until required. Stored cultures of E. fawcettii retained their pathogenicity for more than 12 months under these conditions, but fresh cultures of $A$. alternata needed to be multiplied on $1 / 2$ PDA about three weeks prior to use. On the day of inoculation, A. alternata plates were flooded with sterile rainwater, gently scraped to dislodge spores, and then strained into a spray applicator. Colonies were cut from the E. fawcettii plates, macerated in sterile rainwater and strained into the same spray applicator containing the $A$. alternata spores. The mixture was made up to volume and sprayed onto seedlings, with 10-20 plates (90mm diam.) of A. alternata and 6-8 plates of E. fawcettii sufficient to prepare $5 \mathrm{~L}$ of suspension, which was enough to inoculate about 5,000 seedlings. Prior to inoculation, vigorously growing seedlings were shifted from the greenhouse into a high humidity room set at $\sim 25^{\circ} \mathrm{C}$, sprayed with the suspension and left under these conditions for 4-7 days. Lighting within the humidity room was not necessary, since citrus seedlings showed no adverse effects from being kept in total darkness for seven days. After incubation, the seedlings were returned to the greenhouse for symptom development. Within 5-8 days the seedlings were culled for $\mathrm{ABS}$ symptoms and after a further 5-21 days they were culled for CS symptoms. Culling for ABS needed to be done before the disease caused leaf abscission, whereas CS symptoms were slower to develop and did not cause defoliation. This inoculation procedure was repeated on seedlings three times over a period of 2-3 months to reduce the chance of disease escapes by ensuring inoculation coincided with the availability of soft new growth.

Pathogenicity interference: Fruit from polyembryonic genotypes known to differ in their reaction to both ABS and CS (through repeated field observations under no-spray conditions) were harvested and the seed sown. The hybrid $00 \mathrm{C} 029$ (Fina clementine $\times$ Murcott) is susceptible to ABS but resistant to CS, $06 \mathrm{C} 015$ (Ellendale $\times$ Murcott) is resistant to $\mathrm{ABS}$ but susceptible to $\mathrm{CS}$, and Sweet Orange (Parramatta) was chosen as the genotype resistant to both diseases. Four different spray suspension treatments were applied to these three genotypes: alternaria spores; scab colony-forming-units (cfu); combination of alternaria spores and cfu; and water. Spores/cfu were evaluated at concentrations of $\sim 1 \times 10^{5} / \mathrm{mL}$ and as well as diluted to $1 / 100^{\text {th }}$ of this concentration. The resulting experiment had 27 treatments, each of which were applied to 20 seedlings. Immediately following the application of the spray suspension the seedlings were shifted to a sealed room and maintained at $23-26^{\circ} \mathrm{C}$ and $\sim 99 \%$ humidity (ultrasonic humidifier, Medescan, Australia) for seven days without light (see above).

Technique verification: To verify the effectiveness of the new co-inoculation technique, vigorously growing hybrid seedlings resulting from the 2014 and 2015 pollinating seasons were spray inoculated and incubated at $23-26^{\circ} \mathrm{C}, \sim 99 \%$ humidity and in darkness for seven days. They were then shifted back to the greenhouse where individual seedlings were culled as they showed symptoms of $\mathrm{ABS}$ and/or CS.

\section{RESULTS AND DISCUSSION}

Surveys of field progeny blocks showed an extremely low incidence of hybrids with ABS symptoms $(<0.01 \%)$ but $17 \%$ of hybrids with CS symptoms. This is consistent with a breeding population that has been screened for ABS but not for CS. The incidence of CS was highly dependent on the parents of the hybrids, with many families showing no susceptible individuals while a few families had close to $100 \%$ infection. Segregation ratios suggest that only a small number of genes are involved in conferring resistance, and whilst it was not possible to conclude parental genotypes it was clear that removing CS susceptible hybrids would still leave a workable number of genetically resistant siblings for most families. Thus removing hybrids susceptible to both ABS and CS was not going to compromise the breeding program. It was also clear from the field survey that CS susceptible individuals needed to be removed prior to field planting in order to avoid the costly task of culling large field trees and the inefficient use of field space created by the resulting gaps. 
Table 1 shows the main results of treating different genotypes with spore/cfu suspensions of the pathogens either alone or in combination. It is clear that nursery inoculation is an effective means to identify ABS and CS susceptible individuals, and that combining the suspensions does not disrupt their pathogenicity. Dilution of suspension concentration $\left(1 / 100^{\text {th }}\right)$ did not affect the expression of CS symptoms but slightly reduced ABS symptom development. The suspensions can therefore be applied across a wide range of concentrations.

There are some important differences between the two pathogens and the diseases they cause that influence how a co-inoculation technique is applied (Table 2). These differences have been important in developing a simple procedure that works reliably.
Bulk treatment of hybrid seedlings from the 2014 and 2015 pollinating seasons showed that the technique could be applied efficiently and effectively during the nursery phase. Large numbers of disease susceptible seedlings were easily identified and removed prior to field planting. Some individual hybrids showed symptoms of both diseases, although it was normally the case that plants with ABS symptoms were removed before CS symptoms had time to express. Segregation behaviour of different parents and families during this nursery screening were consistent with disease incidence observed in field plantings from these same families/parents. As an example of the effectiveness of the technique in removing disease susceptible hybrids, there were 467 hybrid seedlings produced from the cross of Encore $\times 01 \mathrm{C} 011$ and its reciprocal, 217 of which

Table 1. Symptom expression for Alternaria Brown Spot (ABS) and Citrus Scab (CS) on nucellar seedlings of three genotypes spray-inoculated with various combinations of pathogenic strains of Alternaria alternata and Elsinoë fawcettii

\begin{tabular}{cccc}
\hline Genotype & Inoculation & ABS symptoms & CS symptoms \\
\hline \multirow{5}{*}{$00 \mathrm{C} 029$} & A. alternata & + & - \\
& E. fawcettii & - & - \\
& A. alternata + E. fawcettii & + & - \\
\hline $06 \mathrm{water} 015$ & A. alternata & - & - \\
& E. fawcettii & - & + \\
& A. alternata + E. fawcettii & - & + \\
w. alternata & - & - \\
Sweet orange & E. fawcettii & - & - \\
& A. alternata + E. fawcettii & - & - \\
\hline
\end{tabular}

+indicates that symptoms of this disease were expressed, - indicates that symptoms of this disease were not seen.

Table 2. Some differences between the diseases Alternaria Brown Spot (ABS) and Citrus Scab (SC) and their causal organisms that influence screening techniques for a disease-resistance breeding program

\begin{tabular}{lcc}
\hline \multicolumn{1}{c}{ Issue } & A. alternata/ABS & E. fawcettii/CS \\
\hline Cultures readily sporulate & yes & no \\
Rigid colonies require maceration & no & yes \\
Fresh cultures ready for use in (days) & 5 & 21 \\
Fresh cultures retain pathogenicity $>12$ months* & seldom & yes \\
Fully expanded immature leaves susceptible & yes & no \\
Newly emerging shoots susceptible & yes & yes \\
Symptoms develop in (days) & $5-8$ & $14-28$ \\
Symptomatic leaves quickly abscise & yes & no \\
\hline
\end{tabular}

*stored in sealed $90 \mathrm{~mm}$ Petri dishes on half-strength potato dextrose agar at $\sim 6^{\circ} \mathrm{C}$. 
Table 3. Recommended technique to rapidly screening citrus hybrids for Alternaria Brown Spot (ABS) and Citrus Scab (CS) susceptibility

\begin{tabular}{|c|c|}
\hline Step & Activity \\
\hline 1 & Virulent isolates cultured from field symptoms and stored at $\sim 6^{\circ} \mathrm{C}$ on $1 / 2 \mathrm{PDA}$. \\
\hline 2 & Fresh cultures multiplied on $1 / 2 \mathrm{PDA} \sim 3$ weeks prior to screening. \\
\hline 3 & $\begin{array}{l}\text { A. alternata plates flooded with sterile rainwater, gently scraped to dislodge spores, then strained to } \\
\text { remove large debris. }\end{array}$ \\
\hline 4 & $\begin{array}{l}\text { E. fawcettii colonies cut from plates and macerated in sterile rainwater in a homogeniser to produce } \\
\text { colony-forming-units, then strained. }\end{array}$ \\
\hline 5 & $\begin{array}{l}\text { Combine both suspensions in a spray applicator and make up to volume. } 10-20 \text { plates }(90 \mathrm{~mm} \text { diam.) of } \\
\text { A. alternata and 6-8 plates of } E \text {. fawcettii are sufficient to prepare } 5 \mathrm{~L} \text { of suspension, which is enough to } \\
\text { inoculate 5,000 seedlings. }\end{array}$ \\
\hline 6 & $\begin{array}{l}\text { Spray onto vigorously growing seedlings that have been shifted into a high humidity room at } \sim 25^{\circ} \mathrm{C} \text {. } \\
\text { Maintain these conditions for } 4-7 \text { days. }\end{array}$ \\
\hline 7 & Return seedlings to the greenhouse. \\
\hline 8 & $\begin{array}{l}\text { After 5-8 days cull all seedlings showing ABS symptoms (assess prior to ABS causing rapid leaf } \\
\text { abscission). }\end{array}$ \\
\hline 9 & 14-28 days after treatment re-examine remaining seedlings and cull those showing CS symptoms. \\
\hline 10 & Repeat the inoculation procedure to minimise disease escapes. \\
\hline 11 & Field-plant remaining hybrid seedlings. \\
\hline
\end{tabular}

were culled because of ABS symptoms and a further 82 seedlings with CS symptoms. Thus $64 \%$ of hybrids were removed before field planting, $27 \%$ of which would have been missed if the CS screening had not been incorporated. The remaining seedlings from all families have now been planted in the field with no fungicide treatments, and will be observed for symptoms when climatic conditions favour disease development.

The recommended procedure for application of this simple co-inoculation method is shown in Table 3. This new technique is proving highly effective in the Australian breeding program because it: accurately identifies hybrids that are genetically susceptible to two important commercial diseases; removes susceptible individual hybrids prior to field planting; requires simple equipment and limited expertise; fits within existing hybrid production procedures; causes no delays in the breeding process; reduces the size of field progeny blocks; reduces management costs (spraying) of field progeny blocks; removes the need for later-stage disease phenotyping of selections; provides progeny-test data for parents within 18 months.

Incorporation of addition pathogens of commercial significance into the spray suspension warrants examination.

\section{ACKNOWLEDGEMENTS}

This project has been funded by Horticulture Innovation Australia Limited using the citrus levy and funds from the Australian Government. The Queensland Government has co-funded the project through the Department of Agriculture \& Fisheries.

\section{REFERENCES}

Bitancourt AA \& Jenkins AE (1937) Sweet orange fruit scab caused by Elsinoë australis. Journal of Agricultural Research 54: 1-18.

Cobb NA (1903) Letters on the diseases of plants Alternaria of the citrus tribe. Agricultural Gazette of New South Wales 14: 955-986.

Fawcett HS (1936) Citrus diseases and their control. New York: McGraw-Hill. 656 p.

Hutton DG \& Mayers PE (1988) Brown spot of Murcott tangor caused by Alternaria alternata in Queensland. Australasian Plant Pathology 17: 69-73. 
Miles AK, Newman TK, Gultzow DL, Parfitt SC, Drenth A \& Smith MW (2015a) Commercial-scale Alternaria brown spot resistance screening as the first step in breeding new mandarins for Australia. Acta Horticulturae (1065): 971-978.

Miles AK, Tan YP, Shivas RG \& Drenth A (2015b) Novel pathotypes of Elsinoë australis associated with Citrus australasica and Simmondsia chinensis in Australia. Tropical Plant Pathology 40: 26-34.

Pegg KG (1966) Studies of a strain of Alternaria citri Pierce, the causal organism of brown spot of Emperor mandarin. Queensland Journal of Agricultural and Animal Sciences 23: 15-28.

Swingle WT, Robinson TR \& Savage EM (1931) New citrus hybrids. Washington: United States Department of Agriculture Circular. 19 p. (Circular, No. 181).
Timmer LW (2000) Scab diseases. In: Timmer LW, Garnsey SM \& Graham JH (Eds). Compendium of citrus diseases. Saint Paul: APS Press, p 31-32.

Traub HP \& Robinson TR (1937) Improvement of subtropical fruit crops: citrus. Yearbook of the United States Department of Agriculture 1937: 749-826.

Winston JR (1923) Citrus scab: its cause and control. Washington: United States Department of Agriculture. 35 p. (Bulletin, No. 118).

Winston JR, Bowman JJ \& Bach WJ (1925) Relative susceptibility of some Rutaceous plants to attack by the Citrus-scab fungus. Journal of Agricultural Research 30: 1087-1093.

Received: November 15, 2016 Accepted: August 30, 2017 